\title{
粗さのある曲り円管の流動抵抗*
}

\author{
須 藤 浩 三*1, 高 見 敏 弘*1
}

\section{Flow Resistance of Curved Pipes with Rough Surfaces}

\author{
Kouzou SUDOU and Toshihiro TAKAMI
}

\begin{abstract}
Friction coefficients have been measured for turbulent flows through curved circular pipes with rough surfaces. An experiment has been carried out under the conditions of equivalent relative roughness $k_{e} / d=3.59 \times 10^{-3} \sim 3.25 \times 10^{-2}$, Reynolds number $R e<7 \times 10^{4}$ and curvature radius ratios $R_{c}$ $=15,30$ and 45 . An approximate expression, which expresses the experimental results well, has been derived using the boundary layer approximation.
\end{abstract}

Key Words: Turbulent Flow, Pipe Flow, Boundary Layer, Curved Pipe, Roughness, Friction Coefficient

\section{1. 緒}

曲り管が用いられている種々の工業機器の使用状況 をみると，曲り管内面はある粗さをもつことが多く， 粗い壁面をもつ曲り管内流れの流動損失を把握してお くことは工業上重要である。粗さのある曲り管内流れ に関する研究は少なく，粗い管壁を有する円形断面の ベンドについての実験(1)が報告されている程度であ る.

このような現状にかんがみ，著者ら ${ }^{(2)}$ は粗い壁面か らなる曲り正方形管内流れの流動抵抗について報告し た、しかし，工業上は正方形管よりも円管を用いるこ とのほうが多い。そこで, 粗い壁面からなる曲り円管 内流れの管摩擦係数を測定し、流動抵抗に及ほす壁面 の粗さおよび曲りの影響を明らかにするとともに，境 界層近似により測定結果をよく説明できる乱流管摩擦 係数の表示式を逃出した。

\section{2. 主な 記 号}

$$
d: \text { 管直径 }=2 a
$$

* 平成元年 10 月 14 日 第 67 期至国大会講演会において講演、 原稿受付 平成元年. 5 月 1 日.

*1 正員, 公島大学I学部（７24 東公島市西条町ド見）。

\section{$k_{e}$ :等価粗さ}

$$
\begin{gathered}
p: \text { 無次元圧力 }=\left(a^{2} / \rho \nu^{2}\right) P \\
(r, \theta, \varphi): \text { トーラス座標 }=(R / a, \theta, \varphi) \\
R_{c}: \text { 曲率半径比 }=r_{c} / a \\
R e: \text { レイノルズ数 }=W_{a} d / \nu \\
(u, v, w):(r, \theta, \varphi) \text { 方向の無次元速度 } \\
=(U, V, W) a / \nu
\end{gathered}
$$

$W_{a}:$ 断面平均速度

$$
\lambda: \text { 管摩擦係数 }=\left(-\frac{1}{r_{c}} \frac{\partial P}{\partial \varphi}\right) d /\left(\frac{1}{2} \rho W_{a}^{2}\right)
$$

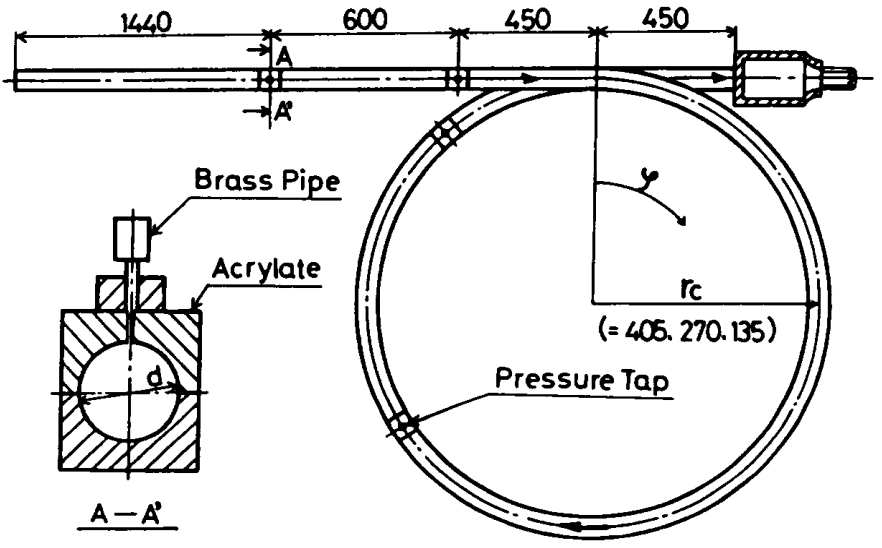

図 1 供試管路の概略 


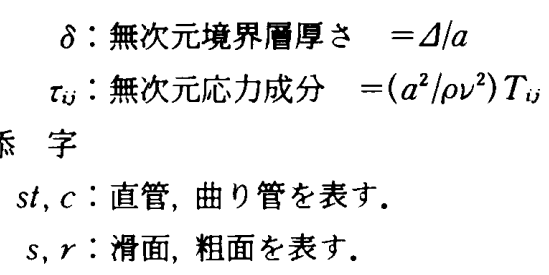

\section{3. 実験}

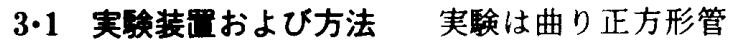

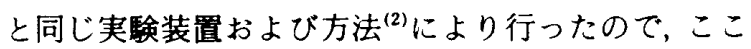
では供試管路のみを図 1 に示す。

供試管路は, 管直径 $d=18.0 \mathrm{~mm}$, 曲率半径 $r_{c}=135$, $270,405 \mathrm{~mm}$ （曲率半径比 $\left.R_{c}=15,30,45\right)$ の曲り円管 で，上流と下流には同じ断面の直円管が接続されてい る. 圧力損失の測定には $R_{c}=15$ の場合： $\varphi=475^{\circ}$, $595^{\circ}, R_{c}=30$ の場合： $\varphi=235^{\circ}, 355^{\circ}, R_{c}=45$ の場合： $\varphi=265^{\circ}, 355^{\circ}$ の位置に設けた直径 $0.5 \mathrm{~mm}$ の静圧孔を 使用した。実験筑囲はレイノルズ数 $R e \fallingdotseq 1000 \sim$ 80000 , 供試流体は空気である。

粗い管路の実験には，管内面に市販の布やすり（呼 び番号：60，80，100，150，240）をはり付けて用いた。 粗さの大きさは, 便宜上ニクラッゼの砂状面粗さ $k_{s}$ に相当する等価粗さ $k_{e}$ により評価した. 図 2 は上流直 管部の管摩擦係数 $\lambda_{s t}$ で, 図中の二点鎖線は層流域の 理論式，一点鎖線はブラジウスの式で

$$
\begin{aligned}
& \lambda_{s t \cdot s}=64 / R e \ldots \ldots \ldots \ldots \\
& \lambda_{s t \cdot s}=0.3164 R e^{-0.25}
\end{aligned}
$$

を示す。粗い管路の管摩擦係数はレイノルズ数の大き

表 1 布やすりの粗さ

\begin{tabular}{|r|c|c|}
\hline NO. & $\lambda s t \times 10^{2}$ & $\mathrm{ke} / \mathrm{d} \times 10^{3}$ \\
\hline 60 & 5.90 & 32.5 \\
\hline 80 & 4.60 & 17.3 \\
\hline 100 & 3.65 & 8.97 \\
\hline 150 & 3.00 & 4.82 \\
\hline 240 & 2.75 & 3.59 \\
\hline
\end{tabular}

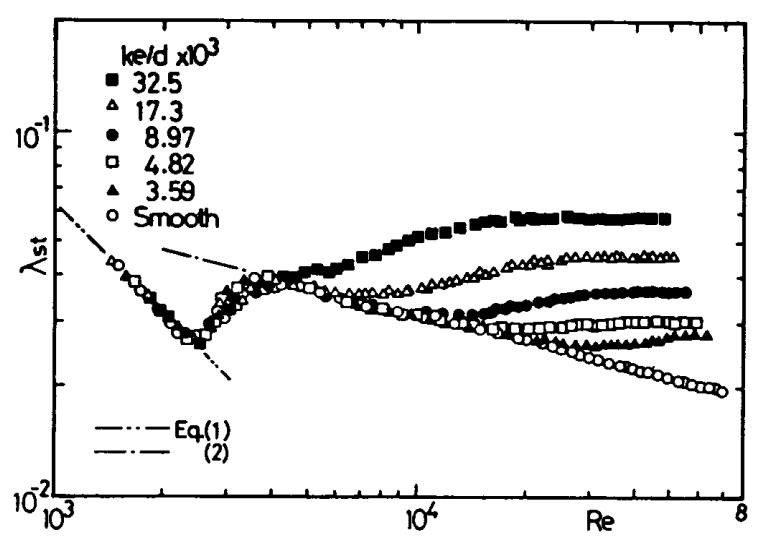

図 2 上流直管部の管摩擦係数
い領域で一定值を示すが，この一定值 $\overline{\lambda_{s t}}$ をニクラッ ゼの式

$$
1 / \sqrt{\overline{\lambda_{s t}}}=1.14-2 \log _{10}\left(k_{s} / d\right)
$$

に代入して $k_{s} / d$ を求め,これを $k_{e} / d$ と表記して等価 相対粗さと名付けた（表 1 参照).

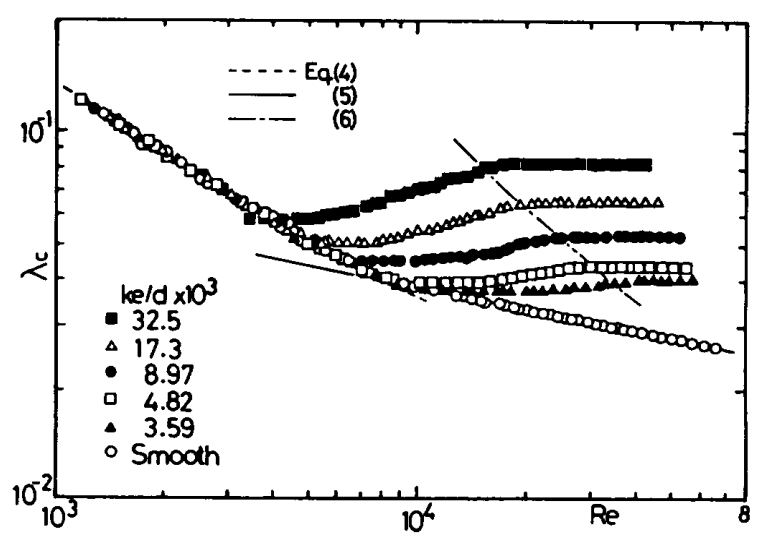

(a) $R_{\mathrm{c}}=15$

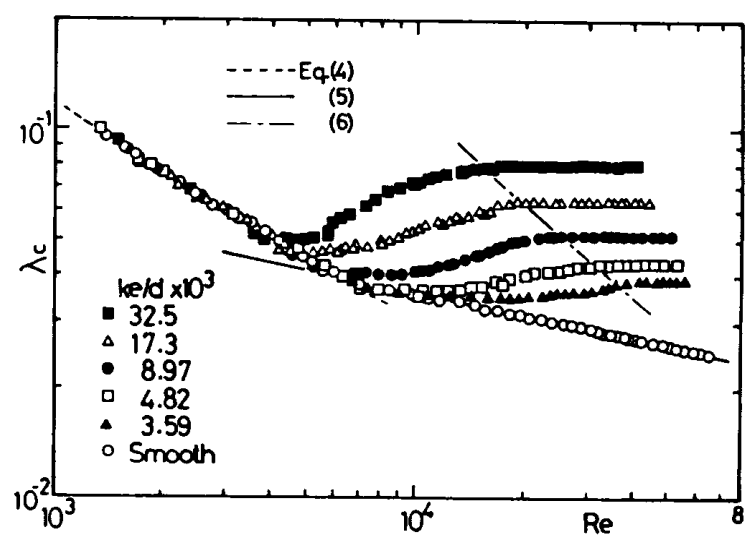

(b) $R_{c}=30$

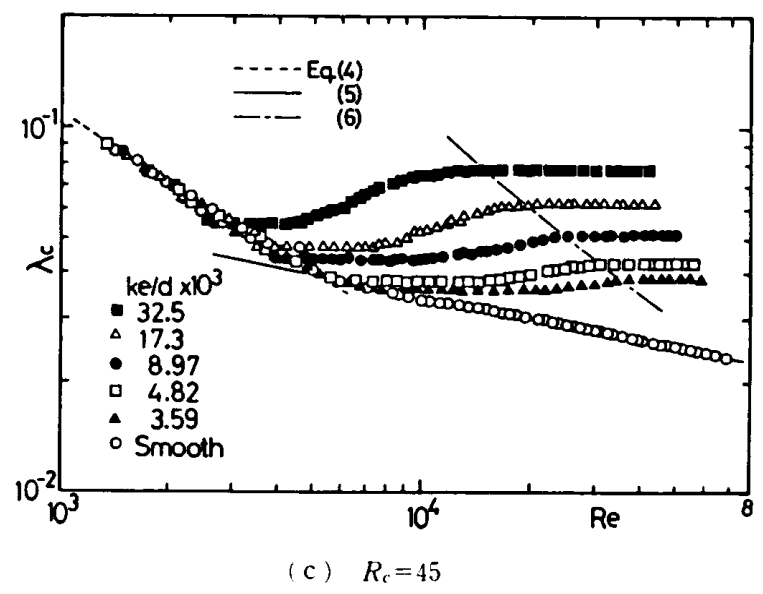

図 3 曲り円管の管摩擦係数 


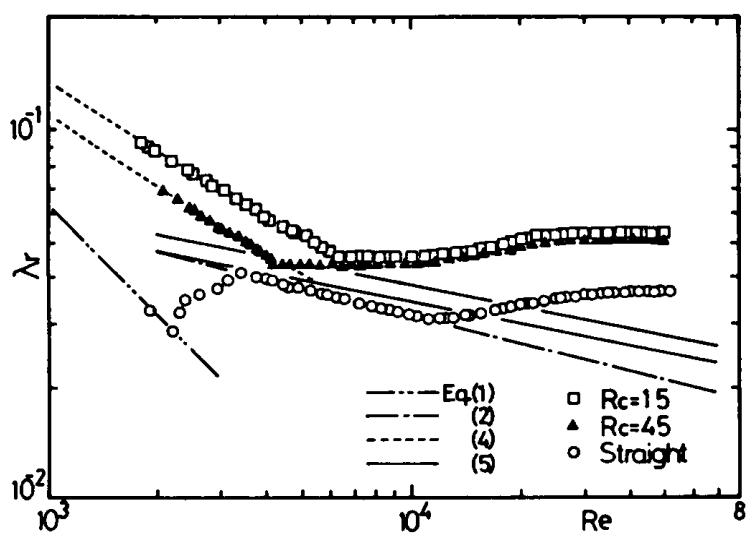

(a) $k_{e} / d=8.97 \times 10^{-3}$

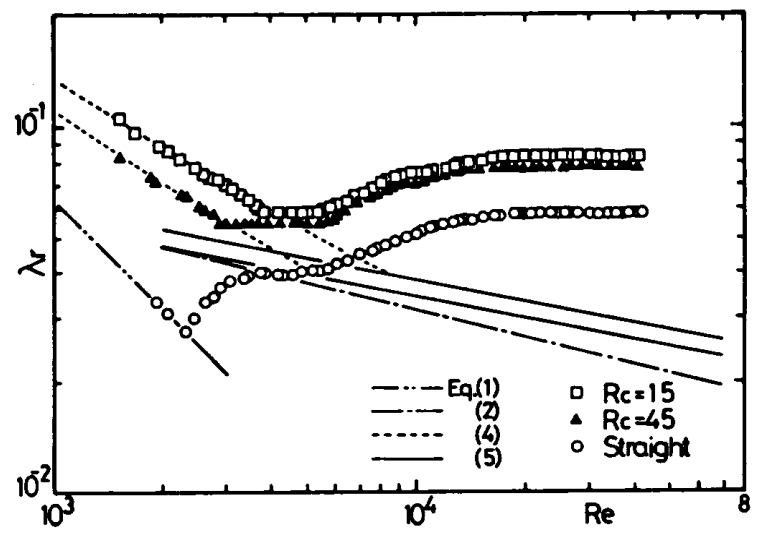

(b) $\quad k_{e} / d=3.25 \times 10^{-2}$

図 4 管摩擦係数の比较

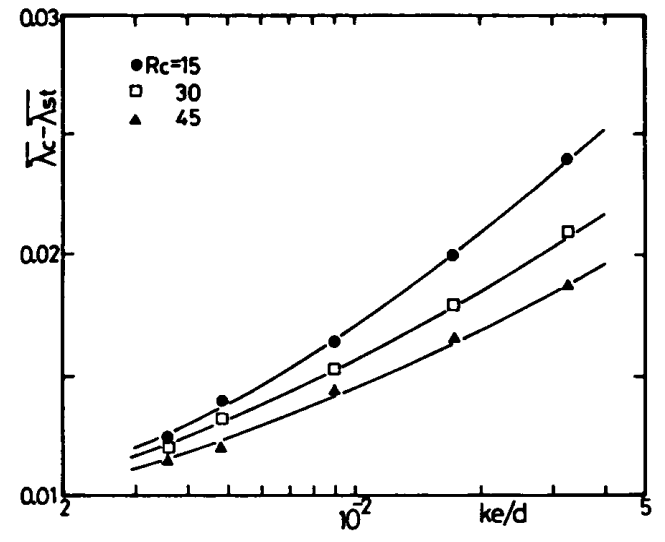

図 5 管摩擦係数差

$3 \cdot 2$ 実験結果および考察＼cjkstart粗さのある曲り円管 に空気を流して測定した管摩擦保数 $\lambda_{c}$ を図 3 に示す。 図中の破線は滑らかな曲り管の首流管摩擦係数 ${ }^{(3)}$

$$
\begin{aligned}
& \lambda_{c \cdot s} / \lambda_{s t \cdot s}=0.1008 D_{e} e^{1 / 2}\left(1+3.945 D_{e}^{-1 / 2}\right. \\
& \left.+7.782 D_{e}^{-1}+9.097 D_{e}^{-3 / 2}+5.608 D_{e}^{-2}\right)
\end{aligned}
$$

$\left[\lambda_{s t \cdot s}:\right.$ 式( 1$\left.), D_{e}=R e / \sqrt{R_{c}}\right]$, 実線は滑らかな曲り管 の乱流管摩擦係数 ${ }^{(4)}$

$$
\lambda_{c \cdot s} / \lambda_{s t \cdot s}=\left\{\operatorname{Re} /\left(R_{c}\right)^{2}\right\}^{0.05}
$$

$\left[\lambda_{s t \cdot s}:\right.$ 式(2)] を示す.

粗さのある曲り管の管摩擦係数 $\lambda_{c . r}$ は粗い直管の 場合と同様の傾向を示している，すなわち，最初は滑 らかな曲り管の管摩擦係数 $\lambda_{c \cdot s}$ と一致しているが, レ イノルズ数が増加すると $\lambda_{c \cdot r}$ は滑らかな $\lambda_{c . s}$ よりも 徐々に大きくなる，そして，図中の一点鎖線よりも大 きいレイノルズ数ではレイノルズ数に依存しない一定 值となる。しかしながら，粗い管の管摩擦係数 $\lambda r$ が滑 らかな管の $\lambda_{s}$ の線上から離れ始める位置，すなわち

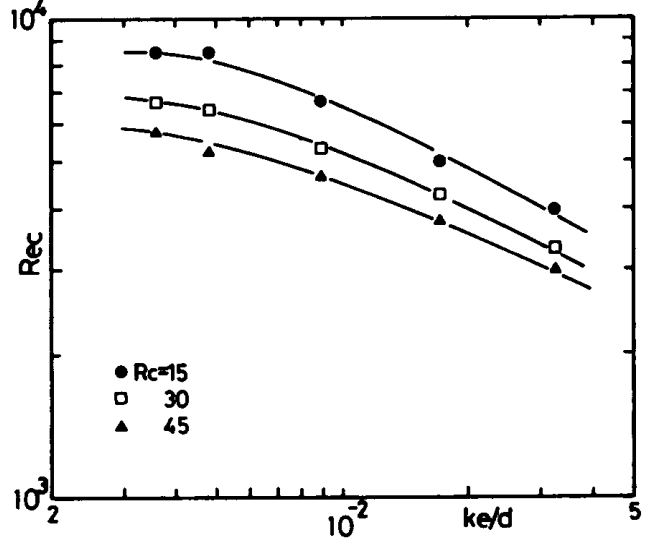

(a) 臨界レイノルス数

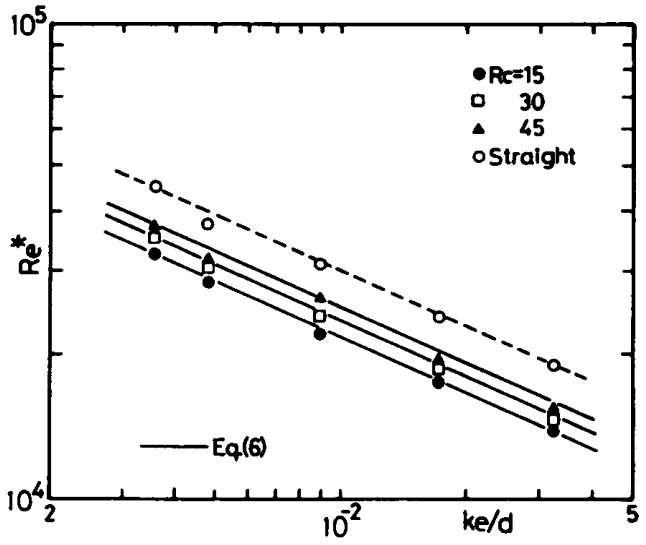

(b) 一定值となるレイノルス数

図 6 レイノルス数

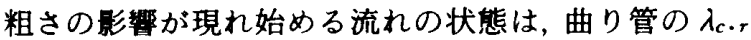
と直管の $\lambda_{s t . r}$ では異なる。粗い直管（図 2 )ではいず れの粗さでも乱流状態の管摩摖係数 $\lambda_{s t} \cdot s[$ 式(2)]の 線上から離れ始めるのに対して，粗い曲り管では粗さ が大きくなると首流状態の $\lambda_{c \cdot s}[$ 式(4)]において粗さ 
の影䇾が現れ始める。このことは，直管内流れと二次 流れを伴う曲り管内流れでは，壁面の粗さにより生ず る影䇾の現れ方が粗さにより異なることを示してい る.

図 4 は同じ粗さの直管と曲り管の管摩擦係数を比較 した結果で,レイノルズ数の增加に伴う $\lambda_{c \cdot r}$ の変化は 曲率半径比 $R_{c}$ に関係なく同様の傾向を示しているが, 曲率半径比が小さいほど乱流管摩摖係数は大きくな る.

図 5 は，一定值となった曲り管の $\overline{\lambda_{c}}$ と直管の $\overline{\lambda_{s t}}$ と の差を求めたものである.図 $2 ， 3$ に示したように，粗 さの増加につれて $\overline{\lambda_{c}}, \overline{\lambda_{s t}}$ はともに増加するが, 両者の 差 $\overline{\lambda_{c}}-\overline{\lambda_{s t}}$ も増加し，曲率半径の小さい管路のほうが 増加の程度は大きい.

図 6 は, 管摩㨲係数 $\lambda_{c . r}$ が屋流管摩擦係数曲線 [式

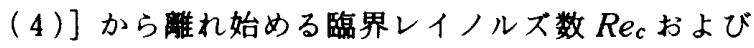
$\lambda_{c . r}$ が一定值となり始めるレイノルス数 $R e^{*}$ を等価 相対粗さ $k_{e} / d$ に対して整理した結果である.曲り正方 形管 ${ }^{(2)}$ の場合と同様に，粗い曲り管の $R e_{c}$ は曲りの強 い管路のほうが大きい值を示すが，粗さが大きくなる と $R e_{c}$ は小さくなり, 曲率半径比による差もやや小さ くなる、このような曲りおよび粗さの影箘は一定值と

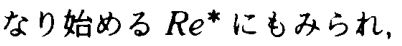

$$
R e^{*}=2570 R_{c}^{0.128}\left(k_{e} / d\right)^{-0.389}
$$

なる式で近似できる、この結果によれば，粗い曲り管 では粗い直管よりも小さいレイノルズ数で管摩擦係数 が一定となる。

\section{4. 近 似解 析}

解析に使用した座標系および流動モデルを図 7 に示 す。管中央部の流れはポテンシャル流れとみなし，壁 面近傍の薄い首（境界層と呼ふ）内の流れには境界首 近似を適用して解析を行う(3)(4). また，次の仮定を設け る.

（1）流れは発達しており，断面内の二次流れの流 線は管壁近くでは境界層を通っている。

（2）曲率半径比 $R_{c} \gg 1$ で, 境界屇厚さ $\delta$ は一定 である。

4・1 管中央部運動方程式および連続の式を満 足する主流および二次流れの速度を，次のように書き $す^{(3)(4)}$.

$$
\begin{aligned}
& u=v_{0} \sin \theta, v=v_{0} \cos \theta \\
& w=w_{0}+\frac{C}{v_{0}} r \sin \theta\left(C=-\frac{1}{R_{c}} \frac{\partial p}{\partial \varphi}\right) \cdots \cdots(7 \cdot \mathrm{b})
\end{aligned}
$$

ここで, $v_{0}, w_{0}$ および $C$ は定数.

$4 \cdot 2$ 境界同運動方程式の各項をオーダ評価し,
微小項を省略すると

$$
\frac{\partial u v}{\partial \xi}-\frac{\partial v^{2}}{\partial \theta}-\frac{\cos \theta}{R_{c}}\left(w_{\mathrm{l}}^{2}-w^{2}\right)=\frac{\partial \tau_{r \theta}}{\partial \xi}
$$

$$
\frac{\partial u w}{\partial \xi}-\frac{\partial v w}{\partial \theta}+C=\frac{\partial \tau_{\varphi r}}{\partial \xi}
$$

なる境界首方程式が導かれる(3)(4).ここで， $\xi=1-r$.

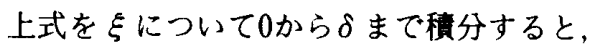

$$
\begin{aligned}
& \left(\tau_{r \theta}\right)_{w}=-u_{1} v_{1}+\frac{d}{d \theta} \int_{0}^{\delta} v^{2} d \xi \\
& +\frac{\cos \theta}{R_{c}} \int_{0}^{\delta}\left(w_{1}^{2}-w^{2}\right) d \xi \\
& \left(\tau_{\varphi r}\right)_{w}=-u_{1} w_{1}+\frac{d}{d \theta} \int_{0}^{\delta} v w d \xi-C \delta
\end{aligned}
$$

なる運動量樌分方程式が莩かれる。ここで, $\left(\tau_{r \theta}\right)_{1}$, $\left(\tau_{\varphi r}\right)_{1}$ はそれぞれ $\left(\tau_{r \theta}\right)_{w},\left(\tau_{\varphi r}\right)_{w}$ に比べて小さいとして 省略した，添字： $1, w$ は境界首外端および壁面を表 す。

4.3 境界置内の速度分布と壁面摩㨲応力

境界 首内の速度 $v, w$ は次の境界条件

$$
\begin{aligned}
& \xi=0: v=w=0 \\
& \xi=\delta ; v=v_{0} \cos \theta, w=w_{1}
\end{aligned}
$$

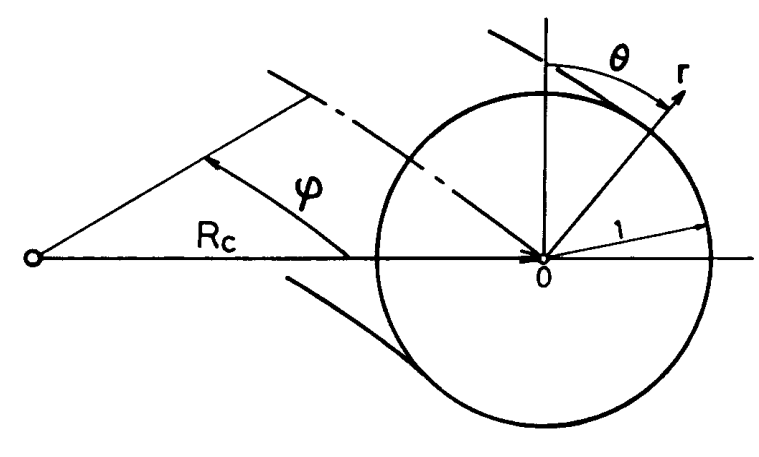

(a) - - 又坐標系

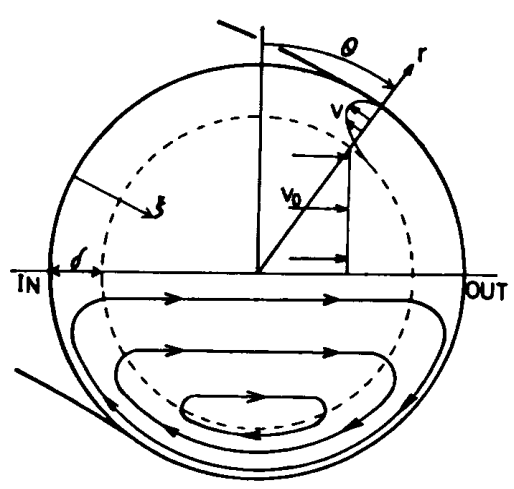

(b) 流動モデル

図 7 坐標系 


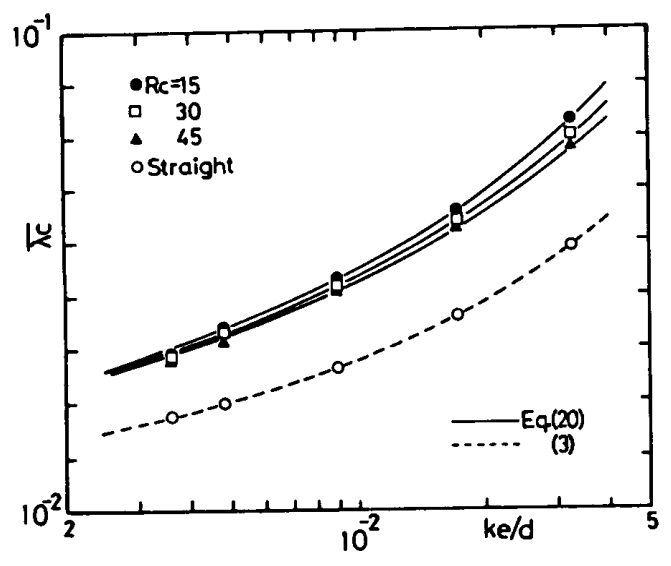

図 8 近似解析による管摩擦係数

を満足し，かつ境界層内を流れる二次流れの流量は管 中央部から境界層内へ流れ込む流量と等しく

$$
\int_{0}^{\delta} v d \xi=-v_{0}(1-\delta) \cos \theta
$$

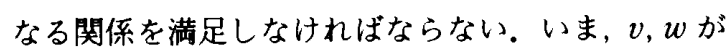

$$
\begin{array}{r}
v=\frac{v_{0} \cos \theta}{(n-1) \delta}\left\{(n+1)(\delta-2) \eta^{1 / n}+2(n+1-\delta) \eta\right\} \\
\ldots \ldots \ldots \ldots(12 \cdot \mathrm{a}) \\
w=w_{1} \eta^{1 / n} \ldots \ldots \ldots \ldots \ldots \ldots \ldots \ldots \ldots \ldots \ldots \ldots \ldots \ldots \ldots \ldots \ldots \ldots \ldots \ldots \ldots \ldots \ldots \\
\end{array}
$$

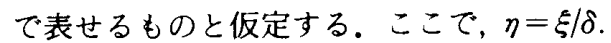

粗い壁面をもつ直円管内乱流において，管摩擦係数 $\overline{\lambda_{s t}}$ がニクラッゼの式 (3)で表され, 速度分布が $1 / n$ 乗則に従うとすれば, 壁面摩擦応力は,

$$
\tau_{w}=\frac{\overline{\lambda_{s t}}}{8} w_{a}^{2}=\alpha w_{1}^{2}
$$

となる.ここで,

$$
\alpha=\frac{\lambda_{s t}}{2}\left\{\frac{n^{2}}{(n+1)(2 n+1)}\right\}^{2}
$$

粗さのある曲り管についてもこの関係が成り立つもの として

$$
\tau_{w}=\alpha q_{m}^{2}
$$

とおく。ここで， $q_{m}$ は二次流れが境界層内で最大とな る位置における合成速度 $\left(w_{m}{ }^{2}+v_{m}{ }^{2}\right)^{1 / 2} て ゙, w_{m} \gg v_{m}$ よ り $q_{m} \fallingdotseq w_{m}\left(w_{m} \fallingdotseq w_{1}\right)$ となる.したがって, 壁面摩擦応 力 $\left(\tau_{r \theta}\right)_{w},\left(\tau_{\varphi r}\right)_{w}$ は

$$
\begin{aligned}
& \left(\tau_{r \theta}\right)_{w}=\frac{v_{m}}{q_{m}} \tau_{w} \\
& \quad \fallingdotseq-\frac{(n+1)}{n}\left(\frac{2}{\delta}-1\right) v_{0} w_{1} \cos \theta \\
& \left(\tau_{\varphi r}\right)_{w}=\frac{W_{m}}{q_{m}} \tau_{w} \\
& \quad \fallingdotseq \alpha w_{1}{ }^{2} \quad \ldots \ldots \ldots \ldots \ldots \ldots \ldots \ldots \ldots \ldots \ldots \ldots \ldots \ldots
\end{aligned}
$$

と表される.

4.4 管摩擦係数 運動量積分方程式 (9)に速度

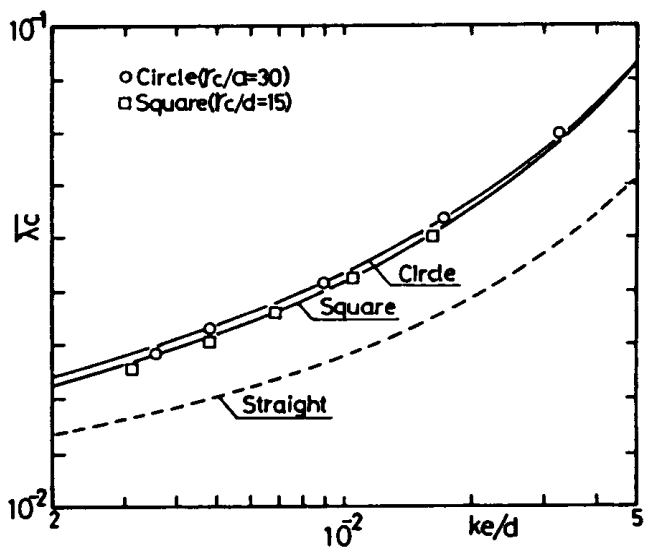

図 9 曲り円管と曲り正方形管の比較

分布 [式(12)］および壁面摩擦応力 [式(14)] を代入 し, 式(9・a)の $\cos \theta$ の項と式(9・b)の $\sin \theta$ の項を取 り出すと,

$$
\begin{aligned}
& \alpha \frac{(n+1)(2-\delta)}{n \delta} v_{0}=\frac{2 \delta}{(n+2) R_{c}} w_{0} \cdots \cdots \cdots(15 \cdot \mathrm{a}) \\
& 2 \alpha C / v_{0}=v_{0}(1-\delta) \cdots \cdots \cdots \cdots \cdots \cdots \cdots \cdots \cdots \cdots \cdots \cdots \cdots \cdots \cdots \cdots \cdots \cdots \cdots \cdots \cdots \cdots \cdots
\end{aligned}
$$

となる，両式を連立し，壁面摩摖応力 $\left(\tau_{\boldsymbol{T}}\right)_{\boldsymbol{w}}$ と压力こ う配 $C$ の釣合いから求まる関係

$$
\begin{aligned}
C & =\frac{1}{\pi} \int_{0}^{2 \pi}\left(\tau_{\varphi r}\right)_{\omega} d \theta \\
& =2 \alpha w_{0}^{2}\left[1+\frac{1}{2}\left\{\frac{C}{v_{0} w_{0}}(1-\delta)\right\}^{2}\right]
\end{aligned}
$$

を用いて整理すると

$$
\left\{(1-\delta) \delta^{2}\right\}^{2} \fallingdotseq 2(1-2 \delta)(2-\delta)^{2}\left(\alpha^{2} \beta R_{c}\right)^{2}
$$

なる境界層厚さ $\delta に$ 関する方程式が得られる。ここで, $\beta=(n+1)(n+2) / n$.

上式の解を $\delta=C_{1} \alpha\left(\beta R_{c}\right)^{1 / 2}+C_{2} \alpha^{2} \beta R_{c}$ の形 $\left(C_{1}\right.$, $C_{2}$ : 定数) に仮定すると，境界首厚さ $\delta$ は

$$
\delta \fallingdotseq 2^{3 / 4} \alpha\left(\beta R_{c}\right)^{1 / 2}-2^{-1 / 2} \alpha^{2} \beta R_{c}
$$

と求まる。

よって管摩擦係数 $\lambda_{c}$ は, レイノルズ数

$$
\begin{aligned}
R e & =2 w_{a}=\frac{2}{\pi} \int_{0}^{2 \pi} \int_{0}^{1}(r w) d r d \theta \\
& \fallingdotseq 2 w_{0}\left(1-\frac{2}{n+1} \delta\right) \ldots \ldots \ldots \ldots \ldots . . .
\end{aligned}
$$

および压力こう配 $C[$ 式(16) ] を用いて

$$
\begin{aligned}
\overline{\lambda_{c}} & =16 C / \operatorname{Re}^{2} \\
& \fallingdotseq 16 \alpha\left(1+\frac{3-n}{n+1} \delta\right)
\end{aligned}
$$

と表される。

解析結果と実験結果の比較を図 8 に示す. 図中の実 線は近似式 $(20)$ による結果で，実験結果とよく一致す 
るように $n=11$ とした． 相対粗さ $k_{e} / d$ の増加に伴い 管摩撩係数が大きくなること, 曲率半径比の小さいほ うが大きいことをよく表しており，本近似解析の結果 が十分に有効なものであることを示している，図 9 は 粗さのある曲り円管[式(20): $\left.r_{c} / a=30\right]$ と曲り正方形

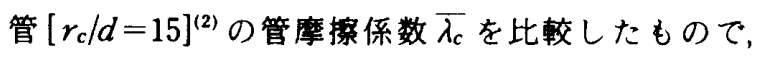
曲り円管のほうが曲り正方形管よりも約 $3 \%\left(k_{e} / d=\right.$ $\left.10^{-2}\right)$ 大きい值を示すが，両者は相対粗さに対して同 じ傾向の変化を示す.

\section{5. 結}

粗さのある曲り円管内乱流について, 曲率半径比 $R_{\mathrm{c}}=15,30,45$, レイノルス数 $R e<7 \times 10^{4}$, 等価相対粗 さ $k_{e} / d=3.59 \times 10^{-3} \sim 3.25 \times 10^{-2}$ の範囲で管摩挜係数 を測定し，ついで近似解析を行い，次の結論を得た。
は, $R_{c}$ が小さい曲り管ほど大きく, $R e>2570 R_{c}{ }^{0.128}\left(k_{e} / d\right)^{-0.389}$ では一定值を示す。

（2）一定となる乱流管摩擦係数 $\lambda_{c}$ の計算には境 界首近似が適用でき，

$$
\overline{\lambda_{c}}=1.538(1-0.667 \delta) \overline{\lambda_{s t}}
$$

なる近似式で表示できる。ここで,

$\delta=0.609 \overline{\lambda_{s t}} \sqrt{R_{c}}-0.0926 \overline{\lambda_{s t}{ }^{2}} R_{c}$

ここに, 本実験に協力いただいた当時の学部生, 吉田 雅之君に謝意を表する。

\section{文献}

（1）日本機械学会編，管路・ダクトの流体抵抗，(1980)，75.

(2) 須藤・高見, 機論, 55-512, B(1989), 972 .

(3) Ito, H., ZAMM, 49-11(1969), 635.

(4) Ito, H., Trans. ASME, Ser. D., 81 (1959), 123.

（1）粗い壁面をもつ曲り円管の乱流管摩擦係数 